\title{
THE DEVELOPMENT OF SOCIAL WORK EDUCATION IN SPAIN
}

\author{
Dr. Francisco Gómez Gómez \\ Dr. Félix Herrador Buendía \\ Universidad Complutense de Madrid
}

\begin{abstract}
This research note presents briefly the development of the Education for Social Work in Spain. The year 2008 has marked the twenty-fifth anniversary of its incorporation into Spanish Universities as an undergraduate degree. In addition, the academic year 2008-09 has seen the introduction of the qualification, Doctor of Social Work. It also provides some thoughts about the academic situation and status of social work at a global level as a result of the domination of the English and Spanish languages. It also compares the development of social work with studies in other countries, and different forms an understanding of the basis of social work in Europe.
\end{abstract}

\section{RESUMEN}

Esta nota de investigación presenta brevemente el desarrollo de la educación del trabajo social en España. El presente año de 2008 ha conmemorado el veinticinco aniversario de su incorporación a la universidad española como una titulación universitaria. Además, el año académico 2008-09 ha visto la introducción del grado de doctor en trabajo social. Esta situación ofrece algunas ideas acerca del lugar académico y del rango del trabajo social a nivel mundial como resultado de la posición de dominación de las lenguas inglesa y española. También se compara el desarrollo del trabajo social con estudios en otros países y formas diferentes de comprensión de los fundamentos del trabajo social en Europa.

\section{IMPLEMENTATION OF THE STUDY OF SOCIAL WORK}

The development of the study of Social Work in Spain has always been coupled with the professionalization of social workers. Those who joined the University twentyfive years ago, in 1983, acquired the qualification of first-degree graduates with the implementation of the Diploma in Social Work. However, unlike the other academic careers, the social workers were excluded from obtaining the 'Licenciado', the second level of University education, and a Doctoral degree.

The Spanish political transition and the adoption of the Constitution in 1978 was an attempt to develop a 'Model Welfare State' to provide for the people who were on the margin of the production system. This was the sector served directly by the social workers in local public administrations. These administrations were responsible for the management of benefits and social assistance in the Partnership Plan for Social Services (Plan Concertado de Servicios Sociales) which was a partnership between the public and private sectors. 
The subsequent development during the last twenty-five years meant that the Spanish social workers were taking care of the people in the private and the public sector and the management of the private sector. These differences were logical aims in public management (general interest and not for profit) and the private management (with particular interest, for profit, and market competition) with shared leadership in the provision and management of social services, and making possible a partnership, or agreement, between public ownership of the organisation, and also efficient and effective competition of the neo-managerial techniques of private management when the administration loaned its services.

We can say that since the end of the last phase of the dictatorship in Spain, termed 'Developmentalist', and the arrival of democracy, the image of social work has diversified in its professional field of activity beyond the original public sector, the design of social policies, and state confessionalism of the regime of dictatorship.

In the beginning social work was seen as a profession. This profession emerged in Barcelona in 1934, in the context of the Second Spanish Republic, a period marked by political upheaval. The first professionals graduated from the School of Social Work (originally founded in 1932). In 1966 the Ministry of Education (General Directorate of Vocational Education-Training-Section), approved the curriculum, staff, timetables, and examinations for these studies at the School of Social Assistants, which was the predecessor of the future University School of Social Work which was assigned to the University of Complutense in Madrid.

The curriculum consisted of three courses and each of these was structured on religious training. The first course, generically called 'Religious Education', revolved around the four disciplines: General Psychology, General Sociology, Social Service Methodologies, and the Practices of Social Services. The second course, also called Religious Education, was less generic and concerned with the Social Doctrine of the Church. It emphasised the subjects: Differential and Genetic Psychology, Social Structure, Individualized and Group Social Services, and the Practices of Social Services. The third and final course, again called Religious Education, established a moral code which was way beyond the professional code of ethics of today. Centred around this course were such disciplines as: The Techniques of Social Investigation, Social Services and the Community, and the Organisation and Practice of Social Services, being the most prominent.

The 1966 Law governing the curriculum of the School of Social Work put into place the boundaries for the development of social work within the field of teaching nonuniversity officials, and in the context of an educational and pedagogical plan owned by confessional dictatorship.

In 1975 the process for the recognition of university status for the study of social work began. This culminated in 1982 with the regulation of the Studies of Social Assistants. These were designed as university teaching for the 'Primer Ciclo'. This provided the definitive impetus for the incorporation of the Official School of Social Assistants at the Universidad Complutense de Madrid, with its re-naming to the University School of Social Workers ('Escuela Universitaria de Trabajo Social' EUTS). 
In this way, the paper was instrumental in shaping the social assistant and finally incorporating, and subsequently legally designating it, as a social worker. The social worker, as a professional, was assigned the role of an instrument of professional intervention, with the power and ability to manage individual and collective users, who would reinforce the social welfare of the different social structures and lifestyles.

\section{DEVELOPMENT THROUGH THE CONVERGENCE OF THE EUROPEAN HIGHER EDUCATION}

The Agreement in Bologna in 1999 led Spain, five years later, to introduce postgraduate university studies which could be validated in the different European Union countries through the mechanism of the European Credit System (ECTS) and by which means the students could have their studies recognised in any of the member states of the European Union. Each of the university qualifications is structured in terms of profiles and training objectives that are specific in subject and content, and which enable students to be competent in the development of a range of skills and capabilities for their particular qualification.

University qualifications are divided into degree, a basic diploma of a four year duration and 240 credits, and post-graduate degree, divided into a Master and a Doctoral degree. In the academic year 2006-07, Masters degrees in 'Community Social Work: Management and Evaluation in Social Services' and 'Social Welfare: Individual, Family and Group Intervention' were approved and introduced at the University of Complutense, Madrid, the University of Navarra and the University of Valencia.

In Spain, to be awarded a degree in Social Work, it is necessary to obtain 240 ECTS credits. Great importance is placed on practical lectures, external practice and a period of study abroad. And that is where the teaching of social work in Spain, perhaps because it is a more recent discipline, and therefore more flexible, it occupies a prominent position compared with other disciplines. It has the highest level of university consolidation and academics who, for various reasons, have not yet achieved a similar level of professional implementation.

The studies for a Master in Social Work: Management and Evaluation of Social Services, and Social Welfare, Individual, Family and Group Counselling, are worth 120 credits, and require the completion of the public oral defence of the project, at the end of the career. The Masters evaluates the quality within a competitive plan for postgraduate studies at a national level. Both studies have the duration of two academic years.

The academic year 2008-09 saw the introduction of a Doctoral degree in Social Work. This qualification is highest level attainable and is very significant for social work graduates and an important landmark for the profession in Spain. Up until now these graduates could only attain the first level university degree, to obtain the level of Doctoral degree, they would have had to enrol in other related disciplines, such as sociology, psychology, law, education, and communication etc. 
This opportunity for the creation of scientific investigation into social work in Spain gave a new force to this area in Europe. The knowledge that has been gained has led to a huge development world-wide. It will therefore reinforce the development of social work in the English speaking countries, and also in the countries of Spanish and Latin influence also. Up until now, it is in these two areas of the world that social work has expanded most.

Without a uniform development in all continents, and the recognition of social work as an university discipline, we cannot open new horizons in the countries which have been recently incorporated into the European Union, specifically Russia which leads the developments in social work studies.

\section{A PROFESSION WITH A FUTURE IN EUROPE - PROFESSIONALISATION}

Despite what has been written here, we must not forget the existence of other realities in Europe, such as the French and the Germans who differ significantly in the academic and professional development of social work. In Germany the teaching pedagogy has a direct effect on social work and its development in those geographical areas with Germanic influence, although its influence is less confused than with other pedadogic professions.

In France, graduates of Employment Law confused their work with the work of the French social workers but in fact they were unique up until they had a distinct name, social workers, which is well-known and accepted worldwide. As a consequence, as we have shown, social work has failed to develop in these two countries to the level achieved world-wide.

On the $20^{\text {th }}$ November 2008, Spain published in the official gazette: 'Boletin Oficial del Estado', the incorporation into law, of Directive 2005/36/EC of the European Parliament and Council, Directive 2006/100/EC, the professional qualifications which included, the Diploma of Social work. These professional qualifications could be applied to the citizens of other European Union countries, who could work directly in Spain, provided that they had already practiced in their country of origin. We believe that this will safeguard the interests of the professionals of the other European countries, such as the Germans and the French.

The other social democratic countries in Northern Europe are well-known for the levels achieved in their welfare states. These European countries have a greater developed social work which has been attained by freedom given to the profession. In countries such as Finland for example, the social workers are professionals who practise family psychology, more than has been usual in the discipline, but that has contributed to the development of the professional activities of the social workers.

The National Agency for the Quality Assessment in Spain (La Gencia Nacional de Evaluaction de la Calidad: ANECA), was responsible, in 2005 for the publication of the White Paper's professional qualification, 'Degree in Social Work'. Thirty-three Spanish Universities, which offer social work studies (including the authors of this 
work, who provided input from the Univesidad Complutense de Madrid) participated and co-ordinated with ANECA to produce this paper.

At the same time, the White Paper brings together and compares social work studies in the other member countries of the European Union. Although not exhaustive, it reflects the differences that exist between them. It also recognises the different levels of professionalization of social workers in Europe. This is evidenced by the fact that the studies aimed at obtaining a high degree will enable them enter the profession, are very different between the countries of the European Union.

The training of social workers in Spain and Europe is well organised and supported at an international level. There are professional associations, schools of work, and professional colleges which are associated with international organisations. There are, for example, the International Association of Schools of Social Work (Asociaction Internacional de Escuelas de Trabajo Social: AIETS) and the International Federation of Social Workers (Federacion Internacional de Trabajadores Sociales: FITS).

In addition, the White Paper's Degree in Social Work includes some important references to the studies of access to the labour market of graduates in Spain. It is clear that the profession requires the same standards, and has the same importance as the studies of the majority of the professional relations and the other labour graduates.

The new European (Espacio Europeo) Research in Social Work will make possible inter-university and inter-institutional collaboration between different countries by the creation of new initiatives to support, help, and care for European citizens. Which will help to overcome the current crisis which we face, and help people to face up to, and understand their own lives.

\section{REFERENCES}

CAMPANINI, A.M.: "Europeanization Process in Social Italian Work Education". Social Work and Socity. Vol, 5, 2007,

\section{http://www.socwork.net/2007/festschrift/esw/campanini}

GÓMEZ, F.: "Investigation on a new Method of Professional Supervision: The Constellations in Social Work ". Magazine of Social Services and social Policy, $\mathrm{n}^{0} 71$. 2005, Pp. 101-126.

: "Innovation and Improvement of the Educational Quality in Social Work. Innovation and Improvement of the Educational Quality in Social Work ". Social actions and Investigations (22). 2006, Pp. 1-29.

: "the professional intervention: professional spaces and practices ". In: ALEMÁN, C. and FERNANDEZ, T.: Introduction to the social work. Alianza Editorial, S.A. Madrid 2003, Pp. 466-514.

GÓMEZ, F. and MOÑIVAS, A.: "European Convergence, social Work and new technologies = European convergence, social work and new technologies". Notebooks of Social Work (18). 2005, Pp. 57-77. 
GÓMEZ, F. and MUNUERA, P.: "innovating group Experiences in the Second Specialty in Direction and Council to the Boy, Adolescent and Familiar Psycotherapy". II Experiences on experience group innovating in university teaching. Madrid: UCM, 2007.

MOLINA, M ${ }^{\mathrm{a}}$ V.: The Lessons of the Social Work in Spain 1932-1983. Partnereducative study. UPCO, 1994. 
